\title{
Frozen in Time: Orphans and Uncollected Objects in Museum Collections
}

\author{
Janet Ulph \\ * School of Law, University of Leicester. E-mail: ju13@le.ac.uk.
}

ACKNOWLEDGMENTS: The author is grateful to the AHRC for supporting this research with an AHRC Fellowship. This research was first presented in the Property and Trusts section at the Society of Legal Scholars' annual conference at the University of York in 2015.

Abstract: The focus of this article is upon objects in museum collections where legal title is uncertain ("orphans") or where the owner is unknown (deposited objects) or where the owner cannot be found (uncollected loans). Museums may have little choice but to continue to care for these objects even where they are unsuitable to be retained within the permanent collections. It is argued that the current law in the United Kingdom prevents museums from managing their collections properly and rationalising them where necessary. New legislation has been proposed which would assist Scottish museums. It is argued that all museums in the United Kingdom need new legislation which would enable them to manage their collections more effectively, and to approach reviews of collections and disposal of unsuitable objects in a proper and balanced manner, acting for the benefit of the public.

\section{INTRODUCTION}

There is an expectation in the United Kingdom, as elsewhere, that museums should be sustainable and trusted organisations. A museum's sustainability will depend not only upon continuing to attract visitors and supporters but also in acting in a financially efficient manner. ${ }^{1}$ In these austere times, when most museums are suffering severe cuts to their budgets, there may be pressure upon them to identify and dispose of objects in their permanent collections which are not being engaged with by the public or which otherwise are not suitable for retention. ${ }^{2}$ The process of removing unwanted objects, following from a collections review, is often referred to in the United Kingdom as a "curatorially motivated

\footnotetext{
1 Merriman, 2006, 4. Sustainability is concerned with management of resources: Merriman 2006, 28; Dresner, 2002, 30-37.

2 Hadfield, 2011, 89.
} 
disposal." This phrase indicates that the decision to dispose has not been made with a view to raising money from the sale of these objects but has been made for other reasons. ${ }^{3}$

Although deaccessioning and disposal of objects still divides opinion, ${ }^{4}$ it is now generally accepted that it is part of good collections management, as long as it is curatorially motivated (rather than being for the purpose of financial gain), properly resourced and carefully conducted. ${ }^{5}$ Even so, there are risks associated with rationalising collections. Great care needs to be taken to avoid situations where objects are withdrawn on the false assumption that they are not culturally significant when in fact their importance has not been properly understood. ${ }^{6}$ This process of refining a collection, if carried out properly, is therefore time-consuming. But responsible disposal can be beneficial. ${ }^{7}$ The objects earmarked for removal may be transferred to other museums where they can be enjoyed by the public in a new setting. Their disposal should make existing collections easier to manage. ${ }^{8}$ Moreover, if unwanted objects are transferred elsewhere, there will no longer be any need to pay for their care. The process should encourage museums to take a holistic approach towards their collections, ${ }^{9}$ because it acts as a valuable reminder that every new acquisition will have resource implications, as the new addition may need to be analysed and preserved indefinitely.

There can be a variety of reasons why there are unsuitable objects in permanent collections. $^{10}$ For example, some museums have collected indiscriminately in the past because their collections policies were ill defined, or because their staff accepted objects of doubtful cultural value in order to avoid upsetting donors. As a backdrop, there may be a more general problem of storage and care caused by regular acquisition of cultural items over many years. ${ }^{11}$ For example, social history museums may have amassed a large number of objects in order to save them from oblivion and in the hope that they will be valued by future generations. ${ }^{12}$ Managing the agglomeration of so much cultural material has proved a challenge in many countries. In relation to archaeological collections in the United States, Kersel has observed that,

"Storage (here implying curation and permanent care) is one of the most pressing issues facing archaeology today. As collections pile up, space is saturated, cataloging lags, and budget and staff capabilities are stretched beyond their limits; repositories and museums are unable to cope with the burgeoning rates of acquisition, curation, excavation, and retention."13

\footnotetext{
3 By way of contrast, the Disposal Toolkit 2014 defines a "financially motivated" disposal as one where "a primary reason" for disposal is to raise funds by way of sale.

4 Jenkins 2011, 72; Heal, 2006, 32; Ainslie 2004, 235; Robertson, 1995, 168; Stephens 2011-2012, 119; Sonderman 1996.

5 NMDC 2003, 14; Vecco and Piazzai 2015, 221; Brown 2011, 111.

Grosvenor, 2011, 63-64; Brown 2011, 109.

See the thoughtful article by Spalding, 2005, 34.

8 Merriman 2006, 7.

9 Silberman 2015, 61; Green 2015, 63; Kersel 2015, 44, 77.

10 See the "Why Dispose?" section of the Disposal Toolkit 2014, at 8-11.

11 Merriman 2006, 24, 41; Hadfield, 2011, 86. Vecco and Piazzai suggest that typically museums "increase the size of their collection by $1-2 \%$ per year from the moment of their creation:" Vecco and Piazzai 2015, 224. See further, Lord, Lord and Nicks, The Cost of Collecting, 1989.

12 For discussion of the moral obligation owed to future generations and the concern to collect on the basis of "inter-generationality," see Brown 2015; Besterman, 2006, 435; Dresner 2002, 2.

13 Kersel 2015, 44. For discussion of over-collecting and long term curation of archaeological material in the UK, see Owen 2004, 179.
} 
Although the problem of storage may be universal, not every country faces the same challenges. In relation to finding repositories for bulky archaeological material in the United States, Kletter has argued that it is the financial costs which pose problems in relation to storage and there are few difficulties with technology, ethics or the law. ${ }^{14}$ But this article will demonstrate that this is not true in relation to museum collections in the United Kingdom. There are significant legal obstacles regarding managing and rationalising not only archaeological material but also works of art, sculptures, and other types of cultural property.

Most museums in the UK will have objects in their collections which they cannot confidently say that they own. These are sometimes referred to as "orphan collections." It is also typical to find that some objects were left on loan many years ago and the owners cannot be traced. In order to avoid the risks of a legal action and reputational damage, museums may decide to retain these objects despite the fact that, with each passing year, the likelihood of possible owners finally claiming them becomes increasingly remote. Furthermore, a lack of knowledge in relation to whether an object is held on loan and, if so, its precise terms, affects their management even in storage. In particular, a lower duty of care is owed in relation to uncollected loans. ${ }^{15}$ But, where a museum does not know whether the object is an uncollected loan or not, it cannot say with certainty, for example, whether it is appropriate to transfer the object to an off-site storage facility which might be less secure than if it was retained within the museum's main museum buildings.

Museum professionals might ask why, if they have not heard from any possible owner for 50 years or more, the law does not provide that the passage of time has given museums unfettered rights of ownership. Are these unwanted objects to remain "frozen" in perpetuity, to be retained despite the fact that they are occupying much needed storage space and wasting scarce resources? Are any attempts to refine collections to be carried out in a lopsided manner, with orphan objects and uncollected loans excluded from consideration?

This article explores why the current law gives the governing bodies of museums little choice but to retain and care for unwanted items. It discusses proposed new legislation for Scotland, which should resolve many of the problems posed where title to an object is uncertain or where the owner of an uncollected loan object cannot be found. It will be argued that all museums in the United Kingdom need new legislation which enables them to manage their collections more effectively and to approach reviews of collections and disposal of unsuitable objects in a proper and balanced manner, acting for the benefit of the public.

\section{THE LAW OF ENGLAND, WALES AND NORTHERN IRELAND}

\section{A: NO ACQUISITION RECORDS}

\footnotetext{
14 Kletter 2015, 60.

15 Marcus v. Official Solicitor (1997)73 P \& CR D46, C.A.; JJA SA v. Avon Tyres Ltd, 23 Feb 2000; Pedrick v. Morning Star Motors Ltd, 14 Feb 1979, C.A.; Taylor v. Diamond [2012] EWHC 2900; Davis v. Henry Birks \& Sons Ltd (1983) 142 DLR (3d) 356. See Palmer 2009, paras 13-012 - 13-014.
} 


\section{Risks associated with objects which have no acquisition records}

Most museums have some acquisition records from the $19^{\text {th }}$ and $20^{\text {th }}$ centuries which provide little or no information about how an object came to be in their collections. Sometimes objects were transferred by societies which are now defunct and where ownership had been unclear. ${ }^{16}$ Some objects have been deposited anonymously by members of the public, who have either sent objects through the post or quietly left them in the museum before departing. Furthermore, museums have many objects which, although it is known that they were originally transferred on loan, the lenders cannot be found.

It is possible that an object was transferred to the museum on trust for charitable purposes (such as educational purposes). If so, there is little risk of any breach of the law. The Charity Commission encourages museums to root out any objects which do not have merit. ${ }^{17}$ If the governing body is acting in the best interests of the museum and for the benefit of the public in transferring objects to another museum, or selling them and using any proceeds of sale for charitable purposes (such as to acquire new objects or to care for the remaining collections), it is highly unlikely that there will be a breach of charity law.

In contrast, dealing with objects which may have been transferred on loan is hazardous. The lender may have been negligent in failing to remind the museum that the object was lent rather than given and in making no effort to let the museum know of his whereabouts but this carelessness with his own property will not usually affect a museum's liability in conversion. ${ }^{18}$ Similarly, all the efforts which a museum may have made to discover whether the object was on loan or not (such as searching through its acquisition records) will normally be irrelevant. In law, the general rule is that the defendant is strictly liable: there is no defence of good faith. ${ }^{19}$ This potential liability will cause any museum to hesitate in transferring an object elsewhere.

\section{Objects on loan and the tort of conversion}

If a museum sells an object which was on loan, the claimant will use the tort of conversion to recover it or to obtain compensation for its loss. ${ }^{20}$ In law, the claimant merely has to show that the defendant deliberately treated the object in a way which was inconsistent with the rights of the owner and that the defendant's conduct was so extensive that the owner was excluded from possession of it. ${ }^{21} \mathrm{~A}$ claimant is not obliged to show that the museum was at fault. Museums are therefore at risk if they assume that they own their collections where there are no records to substantiate this.

The legal principles which form the basis for the action in conversion are derived from decisions made in cases centuries ago. The law is complex because it requires an

16 Scottish Law Commission 2012. [4.7].

17 Charity Commission 2002. Annex A.1 - A.12.

18 There is no defence of contributory negligence generally available in relation to an action in conversion: Torts (Interference with Goods) Act 1977, sec. 11(1). See RH Willis \& Son v. British Car Auctions Ltd [1978] 1 W.L.R. 438, C.A., 441-443.

${ }_{19}$ Marfani \& Co Ltd v. Midland Bank Ltd [1968] 1 W.L.R. 956, C.A., 970.

20 Torts (Interference with Goods) Act 1977, sec. 3.

21 Kuwait Airways Corp v. Iraqi Airways Co (Nos 4 and 5) [2002] UKHL 19, [2002] 2 A.C. 883, H.L., [39]. 
understanding of subtle issues relating to possession and mental control. For example, the claimant does not need to prove that he is the owner: ${ }^{22}$ he only needs to demonstrate that he has a legal right to immediate possession of the object. ${ }^{23}$ This would be the case where he has transferred the object on loan but where the loan can be brought to an end at any time. It is sufficient if the claimant can show that he has a right to possess the object which is superior to the defendant's right. Thus, a possessor (such as a finder), who exercises control over the object, may have rights which are good against everyone apart from an earlier owner. ${ }^{24}$ By permitting a claimant to assert his possessory rights against anyone who later interferes with his enjoyment of the property, ${ }^{25}$ the law provides a pragmatic solution which avoids social disorder. ${ }^{26}$ Furthermore, by recognising different degrees of possession, the tort is sufficiently flexible to identify who has the better right to an object in the context not only of sales and loans but also of more elaborate transactions. In Kuwait Airways Corp v. Iraqi Airways Co, Lord Nicholls observed that, as conversion could take place in such widely differing circumstances, it was difficult to formulate a precise test. ${ }^{27}$ As Green and Randall have remarked, the courts have tended to look backwards to decided cases over the centuries rather than to look forward with a view to producing guidance which will help with new situations. ${ }^{28}$ As we will see, a lack of a clear legal "map" can create the risk of overhasty decisions.

The normal remedy sought will be financial compensation. ${ }^{29}$ It is possible to ask the court to make an order at its discretion for the return of the object itself where it is unique, as cultural objects often will be. ${ }^{30}$ Where the loan object has been given away or sold by a museum, the claimant has a choice of defendants: as successive possessors will have deprived him of his property in turn, the claimant may sue each one and require them to account for the benefits which they have received. ${ }^{31}$ In Kuwait Airways, Lord Nicholls appeared critical of the principle that each person along a chain of transactions will be held strictly liable to pay compensation, regardless of fault and regardless of whether their possession was for a short period before the object was transferred to another. ${ }^{32}$ But his Lordship went on to acknowledge that the principle of strict liability was "deeply ingrained in the common law."33 The Law Reform Committee had considered this issue in 1971. Its report was the precursor to the Torts (Interference with Goods) Act 1977 which amended and largely unified the old

22 The common law tort of conversion has been amended and encapsulated in the Torts (Interference with Goods) Act 1977, which does not define either proprietary title or possessory title: Government of the Islamic Republic of Iran v. The Barakat Galleries Ltd [2007] EWCA 1374, [2009] QB 22 C.A., [15].

${ }_{23}$ Iran v. Barakat Galleries; RH Willis v. British Car Auctions; Webb v. Chief Constable of Merseyside Police [2000] QB 427, C.A.; Union Transport Finance Ltd v. British Car Auctions Ltd [1978] 2 All E.R. 385, C.A.; MCC Proceeds Inc v. Lehman Brothers International (Europe) [1998] 4 All E.R. 675, C.A..

24 Armory v. Delamirie (1722) 1 Strange 505, 93 E.R. 664; Parker v. British Airways Board [1982] QB 1004, C.A..

25 Costello v. Chief Constable of Derbyshire [2001] 1 W.L.R. 1437, C.A..

26 Parker v. British Airways Board 1009.

27 Kuwait Airways v. Iraqi Airways [39].

28 Green and Randall 2009, 45.

29 Torts (Interference with Goods) Act 1977, sec. 3.

30 Ibid, s. 3 (2) (a). See Somerset v. Cookson (1735) 3 P Wms 390, 24 E.R. 1114; Fells v. Read (1796) 3 Ves 70, 30 E.R. 899; Lady Arundell v. Phipps (1804) 13 Ves 95; Howard Perry \& Co v. British Railways Board [1980] 1 W.L.R. 1375. But the property must be special or unique rather than ordinary stock: Cohen v. Roche [1927] 1 KB 169; Whiteley Ltd v. Hilt [1918] 2 KB 808, C.A..

31 Hollins v. Fowler (1875) LR 7, H.L., 757; Moorgate Mercantile Co Ltd v. Twitchings [1977] A.C. 890, H.L.

32 Kuwait Airways v. Iraqi Airways [79].

33 Kuwait Airways v. Iraqi Airways [80]. 
forms of action to produce the modern action in conversion. ${ }^{34}$ The Committee thought that, if the principle of strict liability was altered, the claimant might face insuperable difficulties in attempting to establish that a defendant in a chain of disposals (such as an auctioneer or dealer) was at fault. The Committee suggested that, as most handlers of goods were professionals who were insured, the advantage of strict liability was that it was clear and certain; it meant that claims could be made on insurance policies without difficulty. ${ }^{35}$ As Lord Denning had noted in $R H$ Willis and Son v. British Car Auction Ltd, ${ }^{36}$ auction houses will normally charge a buyer's premium on every sale and will use this money to pay for insurance to protect not only themselves but also purchasers from potential third party claims. Thus, if a trader or auctioneer does not have the time or inclination to act as a detective to check the ownership history of an object, he can take out insurance to cover the risk of being sued by a third party. Lord Denning described this system as one of "doing justice between the parties" so that they are all protected. ${ }^{37}$ It is therefore difficult to understand why judicial concern to protect commercial people, such as auctioneers, persists when they are so easily able to protect themselves. ${ }^{38}$

The fact that a claimant can sue successive possessors makes it very difficult for museums to find a solution where they wish to transfer or sell (or perhaps destroy) objects from their collections but where there are no records in relation to how they came to be acquired. Not only the museum, but also any recipient, could be sued in conversion if the object turned out to have been originally transferred on loan. Good faith is no defence. Taking out insurance, even if it was possible, would not necessarily be an answer. Museums are concerned to avoid any injury to their reputations because they depend upon public trust. ${ }^{39}$ If a person complains that the museum has sold an object on loan, this action is likely to attract the attention of the media: it will be seen as highly irresponsible by members of the public, who expect museums to care for their collections in the long term and to consult donors before transferring them elsewhere. A further concern is that it is common for the value of cultural objects to fluctuate making it difficult to anticipate the size of any claim for compensation if the object cannot be returned; ${ }^{40}$ museums with unwanted objects may not be able to take out insurance to cover the financial risks of anyone coming forward to claim an object which they have transferred or sold elsewhere. And no museum can insure against reputational damage.

\section{Museum ethics and stewardship of collections}

There are a wide variety of museums in the UK. They include national museums, independent museums and local authority museums. National museums and some

\footnotetext{
34 The main provisions of the1977 Act apply to England, Wales and Northern Ireland but not to Scotland.

35 Law Reform Committee 1971, para. 48, n 2.

36 RH Willis v. British Car Auctions 442-443.

$37 \mathrm{RH}$ Willis v. British Car Auctions 443.

38 Marcq v. Christie Manson \& Woods Ltd [2003] EWCA Civ 731, [2004] QB 286, C.A..

39 Code of Ethics. 2015. Key Principles, Individual and institutional integrity. In Britain Thinks: Public Perceptions of - and Attitudes to - the Purposes of Museums in Society 2013, it was noted at p. 3 that "Museums hold a unique position of being trusted ..." For discussion of the importance of public trust for the museum sector, see Ulph, 2016; Finch, 2011.

40 For a case involving the destruction of a cultural object ("Hole and Vessel II" by Anish Kapoor) which had risen in value by the time of the trial, see Ofir Scheps v. Fine Art Logistic Limited [2007] EWHC 541.
} 
independent museums are charitable. ${ }^{41}$ Legal title to the collections will normally be vested in the governing body, which may be a board of trustees, or a company, or a local authority. All of those who work in these museums, and their governing bodies, are expected to adhere to the Museum Association's Code of Ethics.

Both the current Code of Ethics and its predecessor, published in 2015 and 2007 respectively by the Museums Association, emphasise that museums and their governing bodies act as stewards (or guardians) of their collections. The 2015 Code of Ethics, under the heading of "2. Stewardship of Collections" states as follows:

Museums and those who work in and with them should:

- maintain and develop collections for current and future generations

- acquire, care for, exhibit and loan collections with transparency and competency in order to generate knowledge and engage the public with collections

- treat museum collections as cultural, scientific or historic assets, not financial assets.

The key principle of stewardship is developed further at a later point in the new Code, which speaks of museums "safeguarding items for the benefit of future audiences with its obligation to optimise access for present audiences." 42

\section{Sales and conversion}

Both charity law and museum professional practice encourage museums to review their collections and to deaccession and dispose of objects which are not being engaged with by the public. ${ }^{43}$ If an object is unwanted, museums are expected to try and keep the object within the public domain by transferring it to another museum if they can. The thinking is that a transfer to another museum will benefit the public because there is the opportunity for different visitors to enjoy the object in its new location.

In normal circumstances, museums will only sell an object to a private buyer if it cannot be rehoused in another museum. This occasionally happens either where the object has relatively little cultural value or where there is a surfeit of such objects. The classic examples are things from the Victorian era, such as bed pans and coal scuttles, which may still be of some interest to private purchasers. But, if there is no record of an object's history and if it was in fact transferred on loan, any sale would be a conversion of the object. The lender could therefore sue the museum. The purchaser could also sue the museum demanding the return of the price paid on the basis that there has been a breach of an implied term in the sale agreement that the museum had a right to sell. ${ }^{44} \mathrm{~A}$ museum may therefore be advised that it is safer to keep the object, rather than selling it, in order to avoid any risk of litigation and damage to its reputation.

\section{Stewardship: transfers and loans and conversion}

\footnotetext{
41 See further, Ulph 2015, 179-186.

42 Code of Ethics 2015, Principle 2.1.

43 In relation to guidance from the Charity Commission, see Museums and Art Galleries, Annex A.25-A.27.

44 Sale of Goods Act 1979, sec. 12, Consumer Rights Act 2015, sec. 17.
} 
Although museums will avoid selling objects which have no acquisition records, are they on safer ground if they transfer or lend them to other museums? Museums are encouraged by the Code of Ethics to transfer unwanted objects to other museums. If there is doubt over legal title, the recipient museum could be informed of this and warned that it may be obliged to surrender the object if someone can prove that he is the owner. In these circumstances, could the museums deny that they were converting the object by claiming that they were merely acting as stewards of cultural property? Their argument would be that there had been merely a transfer of physical possession so that the object, although available to be reclaimed, was now to be found in a different location. Both museums would rely upon the guidance in the Code of Ethics to make the point that they held the cultural object as stewards for the benefit of the general public and future generations. They could argue that a transfer would not be asserting any rights to the exclusion of the true owner: it would be simply a matter of swapping one steward for another. If this argument was accepted, museums could feel free to transfer their "orphan collections" between each other and there would be a partial solution to the problem of long term care and storage of unwanted objects.

In order to decide whether the transferring museum or receiving museum is acting in a manner which is inconsistent with the rights of the owner, a court would consider whether they have consciously interfered with the owner's rights. It is a matter of determining whether the defendant has exercised control over the object with the intention of asserting dominion over it. This will normally be the case where someone purchases stolen goods for their own use. ${ }^{45}$ In contrast, a defendant will not be liable if he merely has physical possession of the goods but has no power to deal with them, as may happen when intermediaries transport or store goods. ${ }^{46}$ The courts have struggled at times to determine the liability of intermediaries. However, auctioneers and dealers who have carried out instructions from the apparent owners of goods to sell them have been held liable. ${ }^{47}$ This approach would have made good commercial sense in the $19^{\text {th }}$ century, when it was not uncommon for dealers to agree to buy goods which might be for their own purposes (to buy and then resell) or with the intention of acting as an agent for another. ${ }^{48}$

The courts have been less willing to impose liability where the intermediary has not been directly involved in selling the object in question. In National Mercantile Bank v. Rymill, it was decided that an auctioneer was not liable because he had not effected a sale but had only introduced the seller to a purchaser. ${ }^{49}$ Similarly, in Marcq v. Christie Manson \& Woods Ltd, the Court of Appeal held that Christie's was not liable where, having innocently attempted and failed to sell a stolen painting, it returned the painting to the apparent owner. The claimant was the victim of the theft and sued Christie's, arguing that it was guilty of conversion because it had asserted control over the painting by cataloguing it, offering it for sale, keeping it in its possession for five months and having a contractual lien over it. However, Christie's responded that it had not asserted dominion over the painting: it had not

\footnotetext{
${ }^{45}$ Kuwaiti Airways v. Iraqi Airways; RH Willis v. British Car Auctions; Cochrane v. Rymill (1879) 40 LT 744, C.A..

46 Marcq v. Christie Manson \& Woods Ltd [2004] QB 286, C.A., at [24]; Hollins v. Fowler, 766-767; Consolidated Co. v. Curtis \& Son [1892] 1 QB 495, 498.

47 RH Willis v. British Car Auctions; Consolidated Co v. Curtis; Cochrane v. Rymill.

48 Whether the defendant is purchasing for himself or acting for another may require a careful sifting of the evidence; for example, see the extensive discussion in Hollins v. Fowler 757, 761-762, 773774, 776-778, 786, 789-790, 793, 799-800.

49 National Mercantile Bank v. Rymill (1881) 44 LT (NS) 767, C.A.. The decision was criticised as being too generous to the auctioneer by the Court of Appeal in RH Willis v. British Car Auctions, 443, per Lord Denning MR, 444 per Roskill L.J.
} 
sold the painting and neither had it exercised its lien. ${ }^{50}$ Christie's argument was accepted and it was held that Christie's was not liable for conversion where, having failed to sell the painting, it redelivered the painting to the person who it believed in good faith to be the owner. ${ }^{51}$ Tuckey L.J., with whom Keene and Peter Gibson L.JJ. agreed, stated that Christie's had, "in the event, merely changed the position of the goods and not the property in them." Relying upon the decision in Marcq, one could argue that a museum which transfers a cultural object to another museum where it can be better displayed and enjoyed is merely changing the location of the object. Unfortunately, the recent decision in London Borough of Tower Hamlets $v$. The London Borough of Bromley suggests otherwise; indeed it goes further and raises doubts over the wisdom of a short term loan of a cultural object between museums (such as for a special exhibition) where the ownership history is unknown.

\section{The decision in Tower Hamlets LBC v. Bromley LBC}

The question of whether lending a cultural object to a museum would be seen as an act of conversion was one amongst a number of issues which arose for decision in the case of London Borough of Tower Hamlets $v$. The London Borough of Bromley. ${ }^{53}$ The case concerned a dispute between two local authorities over the ownership of a valuable bronze sculpture created by Henry Moore in 1957. Moore drew on his wartime experiences in London in creating the sculpture. He sold it to the London County Council in 1962, believing that it would benefit Londoners. The sculpture was placed on the Stifford Estate in what is now the London Borough of Tower Hamlets. It was formally titled "Draped Seated Woman" but eventually became known affectionately as "Old Flo." The background to the dispute between the two local authorities was that a now disgraced former Mayor of Tower Hamlets declared in 2012 that the sculpture would be sold at Christie's and the proceeds used to fund social housing projects. Bromley objected to the sale and maintained that the sculpture should stay in the public sector, safeguarded for the benefit of the people of London.

When the London County Council was abolished in 1965, its powers were transferred to the Greater London Council (GLC); when the GLC was abolished in 1986, its powers passed to the London Residuary Body before being distributed amongst various local authorities. Tower Hamlets assumed that it owned the sculpture because it owned the land on which the sculpture had originally been placed. One issue therefore was whether the sculpture was a fixture: if it was, Tower Hamlets would own it because it owned the land. However, Norris J. ruled that the sculpture was a chattel. The ownership of the sculpture therefore depended upon an analysis of the statutory powers under which it had been acquired ${ }^{54}$ and retained ${ }^{55}$ to determine which local authority could claim ownership as successor in title to the London County Council. Norris J. concluded that the relevant statutory powers were the ones concerned with providing works of art for the community as part of an arts education programme (rather than the statutory powers available in connection with housing functions).

\footnotetext{
50 Marcq v. Christie [36]. In contrast, the creation of a lien - if done without authority - will normally be viewed as a conversion where the owner can only recover the goods by paying storage charges: Syeds v. Hay (1791) 4 Term Reports 260; Sang Stone Hamoon Jonoub Co Ltd v. Baoyue Shipping Co Ltd [2015] EWHC 2288.

51 For criticism, see Hudson 2005, 201.

52 Marcq v. Christie [24].

53 London Borough of Tower Hamlets v. London Borough of Bromley [2015] EWHC 1954.

54 Local Government Act 1939, sec. 157.

55 London Government Act 1963, sec, 84, Sch 2(16).
} 
He decided that title to the sculpture had passed from London County Council to the GLC, and then to the London Residuary Body, and then to Bromley.

But this was not the end of the story. When Henry Moore died in 1986, the local press described Tower Hamlets as the owner, believing that this was the case because of the location of the sculpture. Tower Hamlets accepted that this was the position and, in 1992, it made arrangements for the sculpture to be restored after it was damaged by graffiti. In 1996, it lent the sculpture to the Yorkshire Sculpture Park for a three year period. Neither the London Residuary Body nor Bromley made any objections. Indeed, the only reason for Bromley's intervention more recently was to prevent Tower Hamlets from selling the sculpture and dissipating the proceeds.

It was held that Tower Hamlets had acted inconsistently with the rights of Bromley as owner. Norris J. explained that,

"Focusing solely upon the events of 1997-2002, the removal of the sculpture from its site, the contractual loan to the Yorkshire Sculpture Park for three years, the undertaking of further restoration of the sculpture (in addition to the new plinth provided in 1992) and the exercise of control over what work was done, the decision to entrust the insurance of the sculpture to others, the decision to leave the sculpture where it was rather than to bring it back to Tower Hamlets (certainly deliberate by 2002) were all assertions of rights of dominion over the sculpture inconsistent with the ownership rights of Bromley."

Norris J. decided that the conduct of Tower Hamlets was deliberate and was sufficient to exclude Bromley from its use and possession of the sculpture. ${ }^{57}$ As Bromley had not asserted its rights within six years by bringing an action in conversion, its legal title was extinguished by the Limitation Act $1980 .{ }^{58}$ As a result, Tower Hamlets owned the sculpture.

Norris J. rejected Bromley's argument that Tower Hamlets had not exercised any rights of dominion over the sculpture but had merely been safeguarding it. Bromley had relied upon Fouldes v. Willoughby, ${ }^{59}$ and Norris J. noted that it had been held in that case that a "simple asportation of a chattel, without any intention of making any further use of it, was not sufficient to establish conversion." ${ }^{60}$ But Norris J. added that it was also clearly decided in that case that:

"Any asportation of a chattel for the use of the defendant, or a third person, amounts to a conversion; for this simple reason, that it is an act inconsistent with the general right of dominion which the owner of the chattel has in it, who is entitled to the use of it at all times and in all places. When, therefore, a man takes a chattel, either for the use of himself or of another, it is a conversion....".

Norris J. added:

"When Tower Hamlets took the sculpture for restoration (its own purposes) and for contractual loan to the Yorkshire Sculpture Park (the use of a third person) it was not merely moving the sculpture out of harm's way but otherwise permitting the owner to exercise dominion over it; it was acting inconsistently with the general right of dominion of Bromley, inconsistently with Bromley's entitlement to use the sculpture at all times and in all places.

\footnotetext{
56 Tower Hamlets v. Bromley [49].

57 Tower Hamlets v. Bromley [48], citing Kuwait Airways v. Iraqi Airways [39 to 43], [119].

58 Limitation Act 1980, sec. 3(2). An action must be brought within six years of the conversion: ibid, sec. 2.

59 (1841) 8 M\&W 540.

60 Tower Hamlets v. Bromley [50].
} 
Norris J. assumed that Tower Hamlets was acting for "its own purposes" and did not explore Bromley's argument regarding safeguarding the sculpture and stewardship further. Yet, if one considers the conduct of Tower Hamlets during the events of 1992-2002, it is clear that it cared for the sculpture in the same manner as a museum curator would care for a sculpture in a museum collection. After the sculpture had been vandalised, Tower Hamlets liaised with the Henry Moore Foundation which paid for its cleansing and replaced the plinth. It then lent the sculpture to the Yorkshire Sculpture Park making the type of arrangement which in the writer's experience is not uncommon between museums: the loan is free and one party pays for the costs of transport and installation costs (Tower Hamlets in this case) and the other party (the Yorkshire Sculpture Park) agrees to pay for the transport and installation costs upon its return. The Henry Moore sculpture is worth millions of pounds: any private individual or company who owned it might restore it in order to obtain a financial return, such as by selling it or leasing it. However, the evidence in this case points towards Tower Hamlets acting as a steward of cultural property, caring for this cultural object for the public benefit. It is clear that the Henry Moore Foundation would have taken this view: the Foundation is a charity and would not have used its own charity funds to restore the sculpture and to pay for its insurance during the loan if Tower Hamlets was acting for private commercial purposes.

The judgment in Tower Hamlets reveals the difficulties of applying the legal principles in conversion to the actions of bodies which have public purposes and which may not be acting for commercial gain. Although Tower Hamlets was described by Norris J. as acting for its "own purposes" the reality is that the repair or restoration of a cultural object by a public body is carried out on the basis of its importance to the public. This writer discussed the judge's reasoning at a workshop in London for museum curators. I was informed that museums will pay substantial sums of money towards the restoration of "orphan" objects where they are of sufficient cultural importance. The work will be done on the basis that the object deserves to be preserved for the sake of humankind and with a view to making it accessible to members of the public, both in this country and worldwide.

Norris J.'s view that restoration of a cultural object can amount to conversion is important because it now seems that museums which have repaired orphan objects will be viewed as having converted them; it may also mean that these museums may well have title to these objects due to the expiration of the limitation period. Unfortunately, this result provides little satisfaction to museum professionals, who desire certainty in dealing with their collections. Given that there are a large number of objects which may or may not be on loan, and where conditions may or may not have been attached, it is little comfort to know that a repair to an object in the past may end up being significant in providing a limitation period defence to any possible legal claim.

The most disquieting aspect of Norris J.'s judgment is the ruling that the loan of a cultural object to the Yorkshire Sculpture Park amounted to a conversion. This ruling presents a significant dilemma for all museums and their governing bodies. If there is a desire to avoid committing a conversion of an object, then it would appear that museums should avoid lending objects to other museums for exhibition purposes where there are no acquisition records relating to those objects. But there are so many objects which lack acquisition records that this solution is impractical. Museums may well choose to ignore the risk that they may be converting an object because it is a core value within the museum sector that collections should be accessible and enjoyed by all. ${ }^{61}$ The Charity Commission expressly

61 Code of Ethics 2015, Principle 1 "Public engagement and public benefit." 
encourage loans of cultural objects in order to promote public access. ${ }^{62}$ The national museums typically have tens of thousands of objects on loan to museums, other public bodies and researchers. ${ }^{63}$ It is unsatisfactory to find a decision which affects cultural property management but where the real world of professional practice has not been taken into account.

The decision in Tower Hamlets might also be viewed as flawed in failing to fully discuss the reasoning in the case law as it might be applied to public bodies dealing with cultural property. In Hollins v. Fowler, Blackburn J suggested that,

"It is generally laid down that any act which is an interference with the dominion and right of property of the plaintiff is a conversion, but this requires some qualification. From the nature of the action ... it follows that it must be an interference with the property which would not, as against the true owner, be justified, or at least excused, in one who came lawfully into the possession of the goods. And in considering whether the act is excused against the true owner it often becomes important to know whether the person, doing what is charged as a conversion, had notice of the plaintiff's title." 64

Bromley would have had no objection to the Henry Moore sculpture being lent to the Yorkshire Sculpture Park, where it would be safe and where the public would enjoy it. Applying Blackburn J.'s guidance, Tower Hamlet's conduct could be justified or at least excused. In contrast, Bromley strongly objected to the proposed sale at a public auction where the sculpture was likely to be purchased by a private collector and where the proceeds of sale would be spent on social housing. It is surely at this point, where Tower Hamlets could not justify or excuse its actions to the true owner, that there would have been a conversion. If so, Bromley was well within the six year limitation period in bringing its claim.

There are certain key characteristics of conversion which are emphasised in the case law but which cannot be found in the case involving Tower Hamlets. The actions taken by a defendant must be such that the claimant is "deprived" of his property and that he is "excluded" from enjoying it. As Lord Nicholls stated in Kuwaiti Airways Corp v. Iraqi Airways Co,

"For the purposes of this tort an owner is equally deprived of possession when he is excluded from possession, or possession is withheld from him by the wrongdoer ... mere unauthorised retention of another's goods is not conversion of them. Mere possession of another's goods without title is not necessarily inconsistent with the rights of the owner. To constitute conversion detention must be adverse to the owner, excluding him from the goods. It must be accompanied by an intention to keep the goods." 65

If a statue, painting, or other work of art or antiquity is lent by one museum to another, it is difficult to see how a claimant is "deprived" of it: the work of art or antiquity is there, ready to be reclaimed. In the meantime, it is accessible to the public which in most, if not all cases, will be in tune with the true owner's wishes.

The principle that the "use" made of the object must be adverse to the rights of the true owner can also be found in the earlier case of Fouldes $v$. Willoughby, upon which Bromley had relied. For example, Lord Abinger stated;

"In order to constitute a conversion, it is necessary either that the party taking the goods should intend some use to be made of them, by himself or by those for whom

62 Charity Commission 2002. "Public benefit and public access" Annex A.25.

63 NMDC 2003, 11.

64 (1875) LR 7 HL 757, 766 (italics added).

65 Kuwait Airways v. Iraqi Airways [40], [42] (italics added). 
he acts, or that, owing to his act, the goods are destroyed or consumed, to the prejudice of the lawful owner."66

In the same case, Rolfe B. expands on this point by asking:

"suppose I, seeing a horse in a ploughed field, thought it had strayed, and, under that impression, led it back to pasture, it is clear that an action of trespass would lie against me; but would any man say that this amounted to a conversion of the horse to my own use?"67

The idea that the "use" made of the chattel must be in some way adverse to the rights of the owner is a difficult principle to apply to public bodies, such as local authorities or charities caring for works of art and other cultural property for the common good. The courts are accustomed to dealing with cases which involve determining whether the defendant has received a personal benefit, by using or selling the property. ${ }^{68}$ For example, if a thief $(A)$ takes a car belonging to another and then lends it to $X$, this will be a conversion by both $A$ and $X$. It is easy to see why. The owner may need the car to transport him from one location to another: the fact that the car is missing therefore deprives him of the opportunity to use it and forces him to pay to find some other way of travelling. But this reasoning cannot be automatically expanded into a principle that a loan in any circumstances will amount to a conversion.

\section{The impact of the Tower Hamlets decision}

In Tower Hamlets $\angle B C v$. Bromley $L C,{ }^{69}$ there was a fresh hearing before Norris $\mathrm{J}$. in which Bromley sought his permission to appeal his decision regarding the conversion of the sculpture. Norris J. refused permission, noting that Bromley wished to appeal on the basis that:

"I have held that a public body can acquire by conversion a sculpture that had been acquired by public funds for a purpose broader than can be given by Tower Hamlets. I do not accept this. My judgment considers ownership: it does not contemplate a "purpose trust", and the case was not so argued. The only question is whether the sculpture should be in the ownership and control of one local authority or the other. They may have differing ideas about how it should be dealt with and what moral limits should be placed on their statutory powers having regard to the history of the sculpture. But that is not a legal question." ${ }^{70}$

I would suggest, in response, that the purpose of possession is relevant as an evidentiary tool in determining whether the claimant is being excluded from enjoyment of his property. As Lord Nicholls stated in Kuwaiti Airways Corp v. Iraqi Airways Co,

"Whether the owner is excluded from possession may sometimes depend upon whether the wrongdoer exercised dominion over the goods. Then the intention with which acts were done may be material. The ferryman who turned the plaintiff's horses off the Birkenhead to Liverpool ferry was guilty of conversion if he intended to exercise dominion over them, but not otherwise: see Fouldes v. Willoughby (1841) 8 $M \& W 540 . " 71$

66 (1841) 8 M\&W 540, 548, 151 E.R. 1153, 1156.

67 Ibid, 551, 1157.

68 Douglas 2009, 207.

69 [2015] EWHC 2271.

70 lbid, [10].

71 Kuwait Airways v. Iraqi Airways [41]. See further, Green and Randall 2009, 67-68. 
In the Tower Hamlets case, Bromley was arguing that Tower Hamlets had held the sculpture for a public purpose, enabling the public to have access to it. The fact that Tower Hamlets was not making decisions for its own benefit was arguably a factor which needed to be taken into account in determining whether Tower Hamlet had exercised sufficient dominion over the object to exclude the true owner (Bromley) from its enjoyment of its property. This aspect of the decision by Norris $\mathrm{J}$. has a potentially wide impact upon the whole of the museum sector. It would suggest that all museums dealing with orphan objects may be converting them by lending them to other museums. This is surely quite unsatisfactory and the decision is not on all fours with established principles in the law of conversion.

Yet it appears that Norris $\mathrm{J}$. viewed his decision as one which was limited to an analysis of the statutory powers of local authorities. In rejecting the request for leave to appeal, Norris J. stated:

"They argue that I found that the sculpture had been acquired and purchased 'for London' and to conclude that it can now be treated as the property of a particular London Borough is contradictory and cannot be correct as a matter of law, because local authorities are expected to safeguard property, not appropriate it, and authorities have no power to acquire property otherwise than by a Deed of Gift or through another lawful channel. I believe I simply applied the words of the statute and I do not consider that this argument has a real prospect of success..."72

Local authorities operate in accordance with a raft of legislation which governs them, some of which is commercial in character ${ }^{73}$ whilst other legislation encourages local authorities to act to benefit their local communities. ${ }^{74}$ In 1959, the Court of Appeal decided, in $R e$ Endacott ${ }^{75}$ that the functions of local authorities were not charitable. Although the powers and duties of local authorities focus upon serving the local community, this is not enough to achieve charitable status. A body will only be charitable if it benefits the community in a way which the law regards as charitable. ${ }^{76}$ Local authorities have "public" purposes but these are too vague and wide to fall within the narrow legal definition of charity. ${ }^{77}$ It could therefore be argued that the notion of "stewardship" is weaker when applied to local authorities because, unlike charitable museums, they are not currently under any statutory obligation to hold cultural property on trust for the benefit of the public.

However, local authority controlled museums are treated as "stewards" of cultural property in the same way as other museums by the Museums Association, the Arts Council England and other public bodies. The Code of Ethics places severe restraints upon the sale of an object from a museum collection where a reason for the sale is to raise money: ${ }^{78}$ these restraints are designed to force the governing body (including a local authority) to demonstrate that it is acting for the public benefit. If the Code of Ethics is flouted, the museum may be stripped of its accreditation by the Arts Council for a lengthy period. This sanction will mean that the museum is ineligible to apply for public grants. When Northampton Borough Council sold the Egyptian Sekhemka statue at Christie's in 2014

72 [2015] EWHC 2271, [11].

73 See, for example, Local Government Act 1999.

74 See, for example, Local Government Act 2000, sec. 2; Public Services (Social Value) Act 2012, sec. 1(3).

75 [1960] Ch. 232, C.A.

76 Williams' Trustees v. Inland Revenue Commissioners [1947] A.C. 447, H.L.

77 In Re Endacott, Decd. [1960] Ch. 232, C.A., 243-244. See Blair v. Duncan [1902] A.C. 37, H.L.; Houston v. Burns [1918] A.C. 337, H.L. Contrast Re Spence's Estate, Barclays Bank Ltd. v. Stocktonon-Tees Corp. [1938] Ch. 96.

78 Code of Ethics 2015, [2.9]. 
without complying with guidance in the Code of Ethics, its museums were stripped of their accredited status. ${ }^{79}$ If "Old Flo" had been sold, Towers Hamlets would not have been subject to any sanctions because the sculpture was not part of a museum collection; even so, the Arts Council would no doubt have expressed its deep disappointment and Tower Hamlets would have been criticised for treating a cultural object as a financial asset.

By the time that Norris J. had handed down his judgment, the new mayor of Tower Hamlets had declared that Old Flo would not be sold. ${ }^{80}$ Bromley nevertheless attempted to obtain a review of Norris J.'s decision, arguing that Tower Hamlets had not converted the statue either when it was restored or transferred on loan. The Court of Appeal will only grant permission to appeal a lower court's decision if it considers that there is a reasonable prospect of success or if there is otherwise a compelling reason for an appeal to be heard. Norris J.'s decision arguably did not reflect the finer nuances which one can find in decided cases concerning conversion, and it did not pay sufficient attention to the argument that Tower Hamlets was not acting as an owner but was merely caring for the sculpture in accordance with ethical norms applicable to stewards of cultural property. Consequently, one might have expected Bromley to have been given leave to appeal. However, the Court of Appeal rejected the application.

It is unfortunate that the legal principles to be applied in relation to the conversion of cultural property by public bodies has not been explored further. The decision in Tower Hamlets $v$. Bromley presents dilemmas for museums. In order to serve the public, museums are expected to lend objects from their collections for special exhibitions. They are also expected to repair them where appropriate. Yet, according to the decision in Tower Hamlets, these are acts of conversion. Equally, it is part of good collections management to dispose of unwanted items from collections, giving priority to transfers to other museums and, in particular, accredited museums. Yet it now seems clear that a permanent transfer to another museum would also be an act of conversion by the transferring museum, regardless of the fact that the museum did not intend to deny any rights of a third party which might exist. ${ }^{81}$

As a result of the decision in Tower Hamlets, someone who has lent an object to a museum should be able to confidently assert that there has been a conversion of his property where it has subsequently been lent or transferred to another museum. The basis of the claim would be that these actions have interfered with his ownership rights. ${ }^{82}$ However, can a museum which has lent an orphan object (or repaired it) more than six years ago rely upon the Limitation Act 1980 to argue that the claimant's action is now time-barred? This should be the case. Even so, I would suggest that the decision in Tower Hamlets creates considerable uncertainty and may lead to litigation. This is why new legislation is needed which would allow museums to deal with objects with no acquisition records after they have been in the continuous possession of a museum for a specified number of years.

\section{B: UNCOLLECTED LOANS}

\footnotetext{
79 http://www.bbc.co.uk/news/uk-england-northamptonshire-28602849.

80 Atkinson 2015.

81 Caxton Publishing Co Ltd v. Sutherland Publishing Co [1939] A.C. 178, H.L., 201 per Lord Porter.

82 However, a museum is entitled to retain the item whilst it makes its own enquiries regarding the claimant's assertion of ownership: Clayton v. Le Roy [1911] 2 KB 1031, C.A.
} 


\section{Loans for a definite period}

A number of museums may have objects transferred on loan many years ago but whose owners cannot be traced. If the loan is for a stated period of years and that period has come to an end, the lender will be in breach of the loan agreement in failing to collect the object. There may be a contract clause which entitles the museum to dispose of the object as it thinks fit but, even if that is not the case, a museum will eventually be entitled to dispose of $\mathrm{it}^{83}$ provided that it has acted in a way which is "right and reasonable" beforehand. ${ }^{84}$ Admittedly, the law provides relatively little guidance on what conduct is reasonable because there are so many types of situation where a person ends up unwillingly in possession of an object (which could be a landlord, a mortgagee, or a storage company, for example). ${ }^{85}$ However, a museum which has given the owner a number of warnings and waited for a substantial period of time to elapse before finally disposing of the objects should be viewed as having acted reasonably. ${ }^{86}$

\section{Loans for an indefinite period}

In contrast, museums are in an impossible position where loans have been made for an indefinite period, as frequently occurred in the past. If the loan objects are given to another museum or destroyed, this will be a conversion. There is a statutory procedure for disposal of uncollected goods set out in the Torts (Interference with Goods) Act 1977, ${ }^{87}$ which might appear at first sight to be helpful. However, the procedure involves the service of notices for each uncollected object. The procedure is complex, not least because it appears that the notice bringing the loan agreement to an end must actually be received by the owner. ${ }^{88}$ It is therefore of little use to museums for this reason alone. It is also problematic in other respects. It is concerned with sales, enabling a purchaser to obtain a good legal title, whereas museums are keen to transfer objects to other museums where they can. And the object in question might not be easily sellable. The procedure seems to be geared towards commercial transactions, such as landlord and tenant. Instead of using the notice procedure, a museum could choose instead to apply to the court for an order directing sale. ${ }^{89}$ But this route is not popular because it may mean that certain information, such as the poor state of the museum's entries in relation to loans, becomes a matter of public record.

Could a museum dispose of an object in the hope that it could rely if necessary upon the argument that it had acted as an "agent of necessity"? This defence has a narrow scope. It is only available if there is an emergency and it is reasonable to dispose of the property,

\footnotetext{
83 Jones v. Gospel \& White (1988) 76 P \& CR D 43, C.A.

84 Campbell v. Redstone Mortgages Ltd [2014] EWHC 3081; Da Rocha-Afodu v. Mortgage Express Ltd [2014] EWCA 454, [2014] 2 P \& CR D25; Mputu-Mayele v. London Borough of Redbridge Council (2012) EWCA 213; Elvin \& Powell Ltd v. Plummer Roddis Ltd [1933] Solicitors Journal 48; Scotland v. Solomon [2002] EWHC 1886. The museum will be an "involuntary bailee" in these circumstances.

85 Houghland v. RR Low (Luxury Coaches) Ltd [1962] 1 QB 694, C.A., 698; Da Rocha-Afodu v. Mortgage Express [50].

${ }_{86}$ Campbell v. Redstone Mortgages Ltd.; Da Rocha-Afodu v. Mortgage Express.

87 Torts (Interference with Goods) Act 1977, sec. 12, sec. 13, Sch 1. See Palmer 2009, at [13-25-13059].

88 Torts (Interference with Goods) Act 1977, sec. 12(2), Sch. I, Part I. It is suggested in Palmer 2009 at [13-055] that, as Sch. 1 of the 1977 Act uses the phrase "given to the bailor," the notice must actually be received and that "mere proof of posting would be insufficient."

89 Torts (Interference with Goods) Act 1977, sec. 13.
} 
taking account of the interests of the owner and of the museum; ${ }^{90}$ and the museum acted in good faith ${ }^{91}$ and cannot find the owner, or the owner refuses to respond with instructions. ${ }^{92}$ One difficulty is that the museum would need to show that there was an emergency in the sense of a real necessity to dispose of the object. ${ }^{93}$ Where an object could be seen as a threat to health (such as a stuffed bird containing arsenic) which was not covered by insurance, this might be viewed by the courts as an emergency. However, the scope of the defence of agency of necessity is uncertain.

If a museum has sold or transferred an uncollected loan object more than six years before any claim, could it rely upon the decision in Tower Hamlets v. Bromley to argue that, because the claimant failed to act for more than six years after the conversion, his title has been extinguished by the Limitation Act 1980? The answer will partly depend upon the terms of the original loan agreement, which might, for example, permit short term loans. However, it is not clear that the museum could rely upon the decision in Tower Hamlets v. Bromley because, in that case, Tower Hamlets thought it had legal title to the sculpture when it arranged to lend it. In contrast, in relation to an uncollected loan, the museum will be aware that it has no legal title. Any sale might even be viewed as theft of the object and thieves can never gain title to a stolen object. ${ }^{94}$ The law is therefore uncertain in relation to uncollected loans. Unsurprisingly therefore museums may feel forced to retain their uncollected loans forever. Although they would like to dispose of many of them, there seems to be no safe route to do so. A new statute is needed to give museums the power to dispose of objects which are unsuitable to be retained.

\section{C: WHERE THERE IS A RECORD THAT THE OBJECT WAS DEPOSITED ANONYMOUSLY}

\section{Objects acquired in the past}

It is not uncommon for people to donate objects to museums anonymously, either by sending things through the post or simply leaving them at an unattended desk. Lay people, such as museum staff, may well assume that deposited objects have therefore been abandoned by their owners. This analysis is attractive: if someone abandons an object on someone's land or in their buildings, the landowner (such as a museum) is entitled to deal with it as it pleases. However, it is only in rare cases that an object has been abandoned in the eyes of the law. An object which has been mislaid is not one which has been abandoned. ${ }^{95}$ In order to establish that an object has been abandoned, there would need to be evidence that the owner intended to give up his rights to the object and had physically

\footnotetext{
90 Springer v. Great Western Rly Co. [1921] 1 KB 257, C.A.; Sims \& Co. v. Midland Rly Co. [1913] 1 KB 103.

91 Prager v. Blatspiel, Stamp and Heacock Ltd. [1924] 1 KB 566.

92 This could include a situation where the owner refuses to respond and where time is running out: Laurence George Ridyard v. Kenneth Roberts and David Roberts 16 May1980, C.A.

93 Sachs v. Miklos [1948] 2 K.B. 23, C.A.

94 Limitation Act 1980, sec. 4(3).

95 Moffatt v. Kazana [1969] 2 Q.B. 15.
} 
relinquished it. ${ }^{96}$ The challenge will be to find evidence which shows that, on the balance of probabilities, the previous owner intended to give up all legal rights in the object and did not care who took possession and control of it. ${ }^{97}$ If the deposited object is of a type collected by the museum (such as a rare book left in the British Library), it is easier to infer that the owner intended to make a gift of it. Visitors to a museum may take great enjoyment out of engaging with its collections and it may prompt them to donate something of their own as a gift in the hope of giving pleasure to others.

If a museum accepts a gift, it will be free to deal with it as it chooses. Although gifts can be made formally, by executing a deed of gift or by making a declaration of trust, this is not essential. Gifts can be made quite informally, ${ }^{98}$ by delivering an object ${ }^{99}$ with an intention to give. ${ }^{100}$ Where one person delivers an object to another person without any explanation, the courts will look objectively at the words or conduct to determine what that person intended. ${ }^{101}$ Thus, where an object has been delivered anonymously, either by being left in the museum or sent through the post, it should be easy to infer that the original owner intended to give the object to the museum and had done his best to deliver it. ${ }^{102}$ This is one situation where the position seems clear cut. The museum has accepted the gifts and it is the owner: it is therefore free to remove and dispose of any unwanted objects.

\section{A dilemma for museums: objects left by mistake}

Objects which have been deposited anonymously in recent times cause significant problems. One fear is that an object may have been left by mistake. If the museum simply assumes that it is a gift, which it can deal with freely, it would be an unconscious bailee. If so, the museum would not be strictly liable for conversion but, as an exception to this general rule, it would only be liable if it could be shown that it was negligent. This principle was applied in $A V X L t d v$. EGM Solders $L t d .^{103}$ In this case, the claimants had returned a quantity of solder spheres which they had purchased from the defendants. Unfortunately, the carriers mixed 21 boxes of capacitors belonging to the claimants with the spheres and, after they were delivered, the defendants destroyed the whole delivery without making any checks. The defendants had been negligent because the capacitors were easy to distinguish from the solder spheres. Staughton J. held that the defendants were liable to compensate the claimants for the value of the capacitors because an unconscious bailee owed a duty to care to ascertain that the goods were his own before destroying them. But the position is different where the bailee has acted with due diligence. In Robot Arenas Ltd v. Waterfield, the claimant had left property on land which was purchased by the defendant. After making enquiries without success, the defendant destroyed the property because he wrongly assumed that it had been abandoned. Edelman QC (sitting as a Deputy Judge) decided that

\footnotetext{
96 Robot Arenas Ltd. v. Waterfield [2010] EWHC 115, at [14]; Arrow Shipping Co Ltd v. Tyne Improvement Commrs. (The Crystal) [1894] A.C. 508, H.L., 532.

97 This has been described as "divesting abandonment" in Palmer 2009, [26-021]; see Robot Arenas v. Waterfield, [13].

98 Day v. Harris [2013] EWCA Civ 191, [2014] Ch. 211, C.A.

99 Delivery is essential: Cochrane v. Moore (1890) 25 Q.B.D. 57, C.A.; Re Cole [1964] Ch. 175, C.A.

100 Thomas v. Times Books [1966] 1 W.L.R. 911.

101 Day v. Harris.

102 R (Ricketts) v. Basildon Magistrates' Court [2010] EWHC 2358 (Admin), [2011] 1 Cr App R 15.

103 AVX Ltd v. EGM Solders Ltd (The Times, July 7 1982); Palmer 2009, [6-004 - 6-022].
} 
if a possessor makes reasonably enquires and cannot discover if anyone owns the thing in question, he will not be liable for conversion to the true owner if he destroys it. ${ }^{104}$

The decision in Robot Arenas gives some comfort to museums by suggesting that they are able to dispose of unwanted objects provided that they make reasonable enquiries before disposal to ensure that there has been no mistake. However, there is little guidance in relation to what checks should be made. Edelman QC thought that it would depend upon the circumstances; ${ }^{105}$ he suggested that the "more valuable (whether in monetary terms or as a personal item) the property might possibly be, the more ... might reasonably be required."106 There is no guidance regarding how long a museum must wait before disposing of the object. It may be the case that, if an object is small and easy to store, such as a small box containing jewellery or medals, the museum would be expected to keep it for quite a long period of time, whilst continuing to try to contact the owner. In contrast, if the object is hazardous in some respect (such as where it is infested with pests), it would no doubt be reasonable to dispose of it far more quickly.

\section{A dilemma for museums: refusal to accept a gift}

A more significant dilemma for museums is that, even if there was an intention to make a gift, the museum must accept that gift before legal title will pass and it is able to deal with the object as the owner. This principle is illustrated by the decision in $R$ (Ricketts) v. Basildon Magistrates' Court. ${ }^{107}$ In this case, Ricketts had appropriated items of clothing from bags deposited on the ground outside a British Heart Foundation (BHF) charity shop. Basildon Magistrates' Court committed Ricketts for trial at the Crown Court on two charges of theft. Rickets appealed against this decision, arguing that he had taken property which had been abandoned; one cannot steal an object if it belongs to no-one. A person can only be charged with theft if he dishonestly appropriates property "belonging to another" with the intention of permanently depriving the other of it. ${ }^{108}$ This argument was rejected by the Divisional Court. As regards the bags left outside the BHF shop, it was held that the obvious inference was that an anonymous person had intended to make a gift and had done his best to deliver the bags. At the time that Ricketts took things out of the bags, the BHF shop had not taken the bags under its control and therefore could not be said to have accepted them. The bags therefore belonged to the person who was attempting to donate them. Ricketts could therefore be charged with theft because the items belonged to someone and were not ownerless.

One might assume that a museum would automatically accept any anonymously deposited gifts to enable it to deal with them as the owner. Unfortunately, it is not as simple as that. If a museum accepted a donation then disposed of it a few months later, and this became known, there could be a public outcry. For example, the Combined Military Services Museum accepted a donation of medals and then sold them a few months' later. When the donor discovered that the medals had been sold, she was horrified because the medals had been bestowed upon her father and she had understood that they would be kept by the

\footnotetext{
Robot Arenas v. Waterfield, [17] - [19], [90-91].

Robot Arenas v. Waterfield, at [91].

Robot Arenas v. Waterfield, at [22].

[2011] 1 Cr. App. R. 15; noted with approbation by Ormerod 2011, 505.

Theft Act 1968, sec. 1(1).
} 
museum forever. This story was splashed across some national newspapers and the museum was roundly condemned. ${ }^{109}$

Museums now take great care when they receive offers of gifts for their collections. For example, Principle 2.2 of the 2015 Code of Ethics states that museums "Collect according to detailed, published and regularly reviewed policies that state clearly what, how and why the museum collects." Museums are now determined to avoid collecting objects which do not fit within their Acquisitions Policy or which will not be of interest to the public. If an object is offered and accepted, museums are increasingly ready to spell out to the donor that the object may be disposed of at a later date. Yet this type of conversation cannot occur where the donation is sent or deposited anonymously. A museum is not forced to accept a gift but, if it does not, the object continues to belong to the benefactor. ${ }^{110}$ Unfortunately, this means that a museum which refuses to accept an object, attempts unsuccessfully to find the owner and then disposes of it, may be held liable in conversion if the true owner then brings a legal action. In short, museums are placed in an almost impossible position by the law in attempting to satisfy their ethical professional standards. In my view, new legislation allowing museums to obtain legal title to lent or deposited objects after a set period of time (as the Scottish Law Commission has suggested for Scottish museums) would be the best way to resolve the museums' difficulties.

\section{SCOTTISH LAW}

\section{Introduction}

Scottish museums suffer the same dilemmas as their English counterparts at the moment: they have objects in their collections which are "frozen in time" because, for example, they lack acquisition records or because they are uncollected loans. The Scottish Law Commission has put forward proposals recommending that Scottish law relating to the acquisition and loss of title to moveable objects should be changed. ${ }^{111}$ These reforms will have a particular impact upon the museum sector but are not limited to that sector; they will apply to any moveable object in Scotland. The Commission has produced a Prescription and Title to Moveable Property (Scotland) Bill and the Scottish Government consulted the public further in 2015. ${ }^{112}$

The Commission's proposals are wide-ranging. In particular, the Commission has proposed to change the underlying basis of the existing law so that anyone could obtain legal title to any type of moveable object by way of positive prescription. It has put forward a "20 year positive prescriptive rule" whereby a possessor of a moveable object who believes that he is the legal owner would obtain the legal title to it after a period of 20 years if he had acted in

\footnotetext{
109 See, for example, Dan Townend, "Heartbreak as Hero's Medals given to Museum in tribute only to have them sold on Ebay" (2015) The Daily Express 10 August.

110 Day v. Harris at [71]. See further, R (Ricketts) v. Basildon Magistrates' Court; Dewar v. Dewar

[1975] 1 W.L.R. 1532.

111 Scottish Law Commission 2012.

112 Scottish Law Commission 2015.
} 
good faith and without negligence throughout that period. ${ }^{113}$ Innocent recipients of stolen property could take advantage of this rule, but thieves and those who recklessly or negligently fail to carry out enquiries would not be able to do so. In developing fresh principles to deal with title conflicts, the Commission faced a fine balancing act. If the rules were too generous to possessors, it would encourage theft and careless dealings with objects, where recipients shut their eyes to suspicious circumstances. On the other hand, it is important to support the marketability of goods by offering some protection to purchasers. The Commission therefore provided rules which went some way towards protecting those who were careful and which encouraged the true owners to publicise their loss.

\section{Lent or deposited property}

The 20 year positive prescription rule will not help museums which know or fear that they possess objects on loan because they cannot say in good faith that they believe that they are the owner. However, the Bill contains a second set of provisions which would assist museums significantly. It would enable possessors to obtain ownership of objects which were deposited with them or lent to them. This would be possible where the original owners (or their successors) have not asserted their proprietary rights at any time during a 50 year period and are untraceable despite the exercise of reasonable diligence to locate or communicate with them. ${ }^{114}$ The question of whether the possessor has satisfied the test of "reasonable diligence" will depend upon the nature and value of the object; more effort would be expected where the object has a high cultural and financial value. ${ }^{115}$

Professional staff at Scottish museums have welcomed these recommendations because they are seen as eventually bringing clarity and certainty in relation to title. The proposals strike a chord, as many professional staff consider that museums should obtain legal title where they have taken care of objects for a long period of time without knowing who owned them (despite making efforts to discover the truth). As the Commission observe,

The Bill's proposals would allow the item to become part of the collection permanently, or for the item to be disposed of in the appropriate way, such as through transfer to a museum with a more suitable collection or by disposal. ${ }^{116}$

There are further provisions to cover the situation where museums (or other possessors) transfer or sell such objects, enabling their successors to rely in due course on the 50 year period. ${ }^{117}$

However, some museum staff have suggested that a 50 year period is too great. They have argued that, as there are no acquisition records for various objects, it will be a matter of interrogating long-serving employees to find evidence of how long the museum can confidently say that it has been in possession of an object. There may only be evidence of possession for 20 years so that, even if the Bill becomes law, professionals will be counting down for a further 30 years. On the other hand, it is accepted that the law must balance the need to allow museums the freedom to deal with their collections by way of loans, transfers or other transactions, with the need to protect the original owner's rights. A shorter period, such as a 30 year period suggested by some museum professionals when consulted earlier by the Commission, might be seen in some quarters as too generous to mere possessors. $\mathrm{A}$

\footnotetext{
113 Prescription and Title to Moveable Property (Scotland) Bill, sec. 1.

114 ibid, sec. 2.

115 Scottish Law Commission 2012, [4.19].

116 Scottish Law Commission 2015, [2.25].

117 Prescription and Title to Moveable Property (Scotland) Bill, s 2(2)(3). Scottish Law Commission 2012 at [4.23-4.24].
} 
long period of 50 years seems desirable once one appreciates that this period could begin to run from when the object was first lent, if this date is known. ${ }^{118}$ However, as many objects do not have acquisition records, time will normally run from when there is a record that the object was in the possession of a museum. A lengthy period such as 50 years makes it very difficult for an owner to argue that the new law would violate his human right to peaceful enjoyment of his property. ${ }^{19}$

The proposed reforms to Scottish law garnered widespread approval in the museum sector. Yet, as the changes in the law are so fundamental to society and cover every type of moveable property, there may be cause for hesitation. For example, the proposals relating to the 20 year and 50 year periods would apply to dealings in all objects. No exception has been made for property looted from the Jewish community during the Nazi era (1933-1945). The Commission thought that their proposals would be unlikely to affect victims. ${ }^{120}$ Firstly, as regards the 20 year positive prescriptive rule, a possessor could only gain good title if he was in good faith and had acted without negligence. Secondly, as regards the 50 year period in relation to lent and deposited objects, UK museums would still need to consider moral claims even if legal title had been lost. Moral claims are referred to the Spoliation Advisory Panel which may recommend that the museum should return the object to Holocaust victims or their heirs. It should also be said that legal title to looted objects will normally have been lost many years ago. Most countries in Europe offer little protection to the original owner where goods are stolen or misappropriated: it is easy for a good faith purchaser to obtain title after a short period of time. ${ }^{121}$ But this issue illustrates the fact that caution is needed in changing any aspect of personal property law. A rule which applies to all personal (moveable) property may be clear and fair in general but, even so, an exception for Holocaust property may be needed.

\section{CONCLUSIONS}

The current law creates significant problems for museums. Museum ethics and charity law encourage them to reach out to the public in this country and abroad, by lending or transferring works of art and antiquities from their collections. Yet a lawyer may well hesitate to advise a museum that it is entitled to lend an object from a collection where there is uncertainty over ownership because, in the light of Tower Hamlets v. Bromley, the museum may be viewed as converting it. The law also puts pressure upon museums to care for and retain orphan objects and uncollected loans, regardless of whether these objects are of any interest to the public or whether they possess any significant cultural value.

\footnotetext{
118 Ibid, sec. 2; Scottish Law Commission 2012, [4.15].

119 Scottish Law Commission 2012, [1.5]; European Convention on Human Rights, Article 1 of the First Protocol.

120 Scottish Law Commission 2015, [2.09-2.15].

121 Scottish Law Commission 2010, Part 5. In England and Wales, title to a stolen object will be extinguished after a good faith purchaser has possessed it for a period of six years: Limitation Act 1980, sec. 2 , sec. $4(2)$.
} 
Lord Donaldson observed in Parker v. British Airways Board that, "One of the great merits of the common law is that it is usually sufficiently flexible to take account of the changing needs of a continually changing society." ${ }^{122}$ In principle, the law of conversion ought to be flexible enough to take account of the ethical notion of stewardship and the particular position of public bodies caring for works of art and antiquities. However, the decision in Tower Hamlets $v$. Bromley casts doubt upon this possibility. Douglas has observed,

"Conversion remains misunderstood and ignored in many quarters. The tort rarely appears on an undergraduate syllabus ... More worrying is the position of litigants. It remains an almost impossible task for a lawyer to advise a client on the merits of a possible claim when the facts fall outside one of a few well established categories of conversion." 123

Uncertainty in the law is unsatisfactory. It is suggested that the problems which confront museums in dealing with orphan objects and uncollected loans should be dealt with in a comprehensive fashion. The obvious solution would be legislation which only applies to museums and galleries and which provides that they will obtain legal title to objects in their collections after a set period of years provided that they have made reasonable efforts to contact the true owner. An exception could be made in relation to spoliated objects to ensure that the new law does not deprive Holocaust victims of any legal rights which they might have. However, the aim would be to ensure that governing bodies of museums would be in a position to confidently lend, transfer, restore, or otherwise deal with the objects in their collections whilst acting in the public interest.

\section{BIBLIOGRAPHY}

Ainslie, Patricia. 2004. "Deaccessioning as a Collections Management Tool." In Museums and the Future of Collecting. Edited by Simon J. Knell. Aldershot: Ashgate. 235-241.

Atkinson, Rebecca 2015. "Old Flo sale could be dropped by new mayor" Museums Journal 22 June. Available at: http://www.museumsassociation.org/museums-journal/news/19062015-old-flo-salecould-be-dropped

Besterman, Tristram, 2011. "Museum Ethics," In Blackwell Companion to Museum Studies. Edited by Macdonald, Sharon. Blackwell, Oxford. 431-440.

Brown, Alistair. 2015. "Out of Sight: Unseen Public Collections" The Apollo 2 November. Available at: http://www.apollo-magazine.com/out-of-sight-unseen-public-collections/ (accessed on 19.09.2016)

Brown, Mychal. 2011. "Disposal as an Essential Management Tool: The Legal, Ethical and Practical Case for Deaccessioning in the United States." ." In Museums and the Disposal Debate. Edited by Peter Davies. Edinburgh, MuseumsEtc Publishing. 104-117.

Britain Thinks: Public Perceptions of - and Attitudes to - the Purposes of Museums in Society. 2013. Museums Association Report. Avaiable at: http://www.museumsassociation.org/download?id=954916 (accessed on 19.09.2016)

122 [1982] QB 1004, C.A., 1017.

123 Douglas 2009, 198. See also Green and Randall 2009, 61-62. 
Charity Commission, 2002. "Museums and Art Galleries" RR10 (Version 08/02) Annex A.1-A.12.

Available at: http://www.charitycommission.gov.uk/media/95113/rr10text.pdf

(accessed on 19.09.2016)

Code of Ethics. 2015. Museums Association. Available at:

http://www.museumsassociation.org/download?id=1151400 (accessed on 19.09.2016)

Disposal Toolkit. 2014. Museums Association. Available at:

https://www.museumsassociation.org/download?id=1075416 (accessed on 19.09.2016)

Douglas, Simon. 2009. "The Nature of Conversion” Cambridge Law Journal 198-223.

Dresner, Simon. 2002. The Principles of Sustainability. Earthscan Publications, Sterling, VA.

Finch, Derek. 2011. "Deaccession of Art from the Public Trust." 16 Art Antiquity and Law 1-37.

Green, Jack. 2015. "Building Capacity, Sharing Knowledge" 3(1) Journal of Eastern Mediterranean Archaeology and Heritage Studies 63-71.

Green, Sarah and Randall, John. 2009. The Tort of Conversion. Oxford: Hart Publishing.

Grosvenor, Bendor. 2011. "Deaccessioning in Practice: How to Make Sure We Get It Right" ." In Museums and the Disposal Debate. Edited by Peter Davies. Edinburgh, MuseumsEtc Publishing. 5771.

Hadfield, Jessica. 2011. "Deaccession and Disposal: The Theory in Context." ." In Museums and the Disposal Debate. Edited by Peter Davies. Edinburgh, MuseumsEtc Publishing. 85-97.

Heal, Sharon. 2006. “The Great Giveaway,” Museums Journal 106, no 10, October, 32-35.

Hudson, Anthony. 2005. "Auctions and Conversion" 10 Art Antiquity and Law 201-214.

Jenkins, Tiffany. 2011. “Just Say No: You Cannot Be Too Careful in Embracing Disposal.” In

Museums and the Disposal Debate. Edited by Peter Davies. Edinburgh, MuseumsEtc Publishing, 7282.

Kersel, Morag. 2015. "An Issue of Ethics? Curation and the Obligations of Archaeology" 3(1) Journal of Eastern Mediterranean Archaeology and Heritage Studies 77-80.

- 2015. "Storage Wars: Solving the Archaeological Curation Crisis" 3 Journal of Eastern

Mediterranean Archaeology and Heritage Studies 42-54.

Kletter, Raz. 2015. "Storage Wars 1, Curation 0" 3 Journal of Eastern Mediterranean Archaeology and Heritage Studies 55-60.

Law Reform Committee. 1971. Eighteenth Report on Conversion and Detinue. Cmnd. 4774. London: The Stationery Office.

Lord, G., Lord, B. \& Nicks, J. 1989. The Cost of Collecting. Museums and Galleries Commission, London.

Merriman, Nick. 2006. Museum Collections and Sustainability." MLA: Research and Evaluation. Museums Association.1-65.

National Museum Directors' Council (NMDC). 2003. "Too Much Stuff? Disposal from Museums." NMDC, London. Available at:

http://www.nationalmuseums.org.uk/resources/press_releases/pr_too_much_stuff/ (accessed on 19.09.2016). 
Ormerod, David "Theft: Committal Proceedings - Claimant Taking Goods from Outside Two Separate Charity Shops" (2011) Criminal Law Review 505.

Owen, Janet. 2004. "Who is Steering the Ship? Museums and Archaeological Fieldwork." In Museums and the Future of Collecting, ed. S. J. Knell. Aldershot: Ashgate. 179-184.

Palmer, Norman. 2009. In Palmer on Bailment, edited by N. Palmer $3^{\text {rd }}$ ed, Sweet and Maxwell, London.

Robertson lan. 1995. "Infamous Deaccessions." In Collections Management. Edited by Anne Fahy. Routledge, 168-181.

Scottish Law Commission. 2010. Prescription and Title to Moveable Property, Discussion Paper No 144.

- 2012. Prescription and Title to Moveable Property Report, No 228. Edinburgh: The Stationery Office.

- 2015. Prescription and Title to Moveable Property (Scotland) Bill - CONSULTATION, July.

Silberman, Neil. 2015. "Is Every Sherd Sacred? Moving Beyond the Cult of Object-Centred Authenticity" 3(1) Journal of Eastern Mediterranean Archaeology and Heritage Studies 61-63.

Sonderman, R. C. 1996. Primal Fear: Deaccessioning Collections. Common Ground 1(2). https://www.nps.gov/archeology/cg/vol1 num2/fear.htm (accessed on 19.09.16)

Spalding, Vicky. 2005. "Wanted: a Good Home for these Vessels ..." Te Ara: Journal of Museums Aotearoa, 30 (1) 34-35. Available at:

http://www.museumsaotearoa.org.nz/sites/default/files/te ara/3312 - vicky spalding deaccessioning 101.pdf (accessed on 19.09.16)

Stephens, H. H. 2011-2012. "All in a Day's Work: How Museums May Approach Deaccessioning as a Necessary Collections Management Tool." De Paul Journal of Art, Technology \& Intellectual Property Law 22:119-81.

Ulph, Janet. 2015. "Dealing with UK Museum Collections: Law, Ethics and the Public/Private Divide" 22 International Journal of Cultural Property 177-204.

- 2016. "The Museum Association's Code of Ethics 2015" 21 Art Antiquity and Law (forthcoming).

Vecco, Marilena and Piazzai, Michele. 2015. "Deaccessioning of Museum Collections: What do we Know and Where do we Stand in Europe?" 16(2) Journal of Cultural Heritage 221-228. 